ISSN: 1110-5623 (Print) - 2090-0570 (Online)

\title{
RESPONSE TO ANTIOXIDANT OILS ON SEMEN QUALITY OF
}

\section{MANDARAH COCKS}

W. Ezzat; A. M. Rizk and A.A. Habeib

Poult .Bre. Res. Dept., Anim. Prod. Res. Instit., Minis. of Agric., Giza, Egypt

Corresponding Author: Waheed Ezzat; E-mail: dr.waheed-ezzat@yahoo.com

Received: 25/ 10/2018 Accepted: 20 /01/2019

\begin{abstract}
The present study aimed to investigate the effects of olive oil or nigella sativa oil as antioxidant dilutants on semen quality and hatchability upon semen storage at $5^{\circ} \mathrm{C}$. A $3 \times 4$ factorial experimental designs was performed including three dilutant sources \{semen diluted 1: 1 with lake diluent (LD) sered as a control, semen diluted at $1 \mathrm{ml}$ semen: $1 \mathrm{ml}$ with $\mathrm{LD}$ and supplemented with olive oil or with nigella sativa oil (1 $\mathrm{ml} / 100 \mathrm{ml}$ of diluent), respectively $\}$ and four storage time $(0,24,48$ and 72 hours at $5^{\circ} \mathrm{C}$ ). A total number of 60 cocks and 180 hens at 38-week-old were used to provide data on sperm assess and hatchability.

The obtained results show significant $(\mathrm{P}<0.01)$ increased sperm motility $(\%)$, and decreased dead spermatozoa (\%), abnormal spermatozoa (\%) and acrosomal damage $(\%)$ of cocks consequently, better hatchability rate of hens treated with diluted semen with nigella sativa oil (NSO) followed by olive oil (OO) compared to the control during different storage time $\left(0,24,48\right.$ and 72 hours at of $\left.5{ }^{\circ} \mathrm{C}\right)$. Percentage of sperm motility of cocks and hatchability rate of hens were decreased, while dead spermatozoa (\%), spermatozoa abnormal $(\%)$ and acrosomal damage (\%) of cocks were significantly $(\mathrm{P}<0.01)$ increased with the advancement of storage time. Therefore, Nigella sativa oil and olive oil could be used to improve the semen quality of cocks when stored at $5^{\circ} \mathrm{C}$, up to72 hours, as well as hatchability rate of Mandarah laying hens.
\end{abstract}

Keywords:Olive oil-Nigella sativa oil- in vitro storage-semen quality- hatchability. 
W. Ezzat; A. M. Rizk and A.A. Habeib

\section{INTRODUCTION}

Avian spermatozoa are characterized by high proportions of polyunsaturated fatty acids (PUFAs) especially docosatetraenoic acid (C22:4 n6) arachidonic acid (C20:4n-6) which associated with increased susceptibility to reactive oxygen species (ROS) and lipid peroxidation (Surai and Sparks, 2001). Several studies focused on the potential of ROS as one of the prime mediators of infertility. Production of ROS in the reproductive tract is detrimental not only to the fluidity of the sperm plasma membrane, but also to the integrity of DNA in the sperm nucleus (Cecil and Bakst, 1993).

The use of chilled-stored semen is limited by its relatively short time fertilizing capacity (Aurich et al., 1997). Oxidative stress in chicken semen during storage reduced sperm numbers reduced motility, increased percentage of dead spermatozoa and raised the level of lipid peroxidation; these changes would lead to lower fertility (Eid et al., 2006). The survival of ejaculated sperm in seminal plasma alone is limited to a few hours (Ball et al., 2001).

Evidence suggests that nutritional antioxidants such as olive oil and nigella sativa oil have been used in the herbal medicine of different populations specifically in the Middle East ( Siegfried and Hughes, 2012). Giovannini et al. (2004) showed that some biophenols, containing olive oil, may counteract the ROS, mediated cellular damage and related disorders by improving in vivo antioxidant defenses. D'Angelo et al.(2001) demonstrated that olive oil effectively counteracts the cytotoxic effects of ROS in various cellular systems . Masella et al. (2004) found that olive oil antioxidants had the following effects: 1- completely prevented the oxidation of LDL; 2- counteracted the time dependent variations in intracellular redox balance, inhibiting the production of $\mathrm{O}_{2}$ - and $\mathrm{H}_{2} \mathrm{O}_{2}$ and the decrease of glutathione content; 3- restored glutathione reductase and peroxidase activities; and 4- restored the mRNA expression of $\gamma$ glutamylcisteine synthetase, glutathione reductase, and glutathione peroxidase to control values. Al-Daraji (2012) cleared that supplementation of the diluent of aged roosters' semen with olive oil can improve semen quality when semen samples in vitro are stored at $5{ }^{\circ} \mathrm{C}$ for up to $72 \mathrm{~h}$ and olive oil can be used as an efficient tool for improving semen quality during liquid storage of diluted semen. On the other hand, nigella sativa oil has been reported to possess antioxidant activity (Burits and Bucar, 2000). Since nigella sativa oil containing high percentage of unsaturated fatty acids and there are no reports concerning the effect of this oil on male reproductive system or sexual hormones. The fixed oil of nigella sativa oil consists of $50 \%$ linoleic acid, $25 \%$ oleic acid, $12 \%$ palmitic acid, $2.84 \%$ stearic acid, $0.34 \%$ linolenic acid and $0.35 \%$ myristic acid (Cheikh-Rouhou et al., 2007). Tawfeek et al. (2006) demonstrated that beneficial effect of the treatment with Nigella sativa oil as manifested by $85 \%$ increase in the percentage of live/dead spermatozoa, and $0.66 \%$ decrease in the percentage of morphologically abnormal spermatozoa reflecting its antioxidants effect that counteract the $\mathrm{H}_{2} \mathrm{O}_{2}$ effect on spermatozoa. The present study amid to define the effects of olive oil or nigella sativa oil addition to diluted semen in cocks semen quality and hatchability during storage at $5{ }^{\circ} \mathrm{C}$ for up to 72 hours 
Olive oil-Nigella sativa oil- in vitro storage-semen quality- hatchability.

\section{MATERIALS AND METHODS}

The present study was carried out at the Inshas Poultry Research Station, Animal Production Research Institute, Giza,Egypt, during the period from November, 2017 until February, 2018. A $3 \times 4$ factorial experimental designs was performed including three dilutant sources \{semen diluted 1: 1 with lake diluent (LD) sered as a control, semen diluted at $1 \mathrm{ml}$ semen: $1 \mathrm{ml}$ with $\mathrm{LD}$ and supplemented with olive oil or with nigella sativa oil $(1 \mathrm{ml} / 100 \mathrm{ml}$ of diluent), respectively $\}$ and four storage time $\left(0,24,48\right.$ and 72 hours at $\left.5^{\circ} \mathrm{C}\right)$. A total number of 60 cocks and 180 hens at 38-week-old were used to provide data on sperm assess and hatchability. Feed and water were permitted ad libitum. Cocks were habituated to abdominal massage response (3 week period from 38-54 weeks of age) for semen collection according to Zhang and Zheng (2002). Semen characteristics were evaluated every 21 days at 38 and 54 weeks of age. Semen samples were divided into 3 test tubes $(1 \mathrm{ml}$ each) to provide 3 replicates pooled samples per each treatment group. This experimental work was planned to study the effects of olive oil or Nigella sativa oil addition to Lake Extender on semen quality and hatchability during storage at $5{ }^{\circ} \mathrm{C}$ as the method described by Lake (1960) which consisted of sodium glutamate :1.35 g, potassium citrate: $0.128 \mathrm{~g}$, sodium acetate: $0.51 \mathrm{~g}$, glucose :0.80 g, streptomycin sulphate :0.20 g, penicillin $\mathrm{G}$ sodium :0.04 $\mathrm{g}$ and distilled water $: 100 \mathrm{ml}$.

The final extension rate was $1 \mathrm{ml}$ semen: $1 \mathrm{ml}$ diluent. After each storage $(0,24$, $48,72 \mathrm{~h}$ ) period, percentages of sperm motility, dead spermatozoa, abnormal spermatozoa and acrosomal damage were recorded according to Lake (1960).
Sperm motility was estimated on a percentage basis according to Ommati et al. (2013). A spermatozoon abnormal was assessed using eosin-nigrosin staining. Abnormal spermatozoa concentrations were recognized as rates of the total (200) sperm. Acrosomal damage of spermatozoa was determined according to Watson (1975). Artificial inseminations were performed at $4 \mathrm{~cm}$ depth using 0.05 $\mathrm{ml}$ diluent semen / hen at the following periods, 0, 24, 48 and $72 \mathrm{hr}$ and collected 40 eggs/ group, after 21 days hatchability rate was calculated by the following equation:

Hatchability rate $=\frac{\text { Chicks hatched }}{\text { Total eggs }} \times 100$.

A total number of 180 hens of Mandarah strain were used to assess of hatchability. Hens at 38 weeks of age were used and fed on a diet of $2759 \mathrm{kcal} \mathrm{ME} / \mathrm{kg}$, and 16.11, 3.29, and $0.39 \%$ Crude protein, calcium, and available phosphorus, respectively in individual cages. Cocks were fed a commercial diet $(16.02 \% \mathrm{CP}$ and $2828 \mathrm{Kcal} / \mathrm{kg}$ diet) up to 54 weeks of age according to Feed Composition Tables for Animal and Poultry Feedstuffs used in Egypt (2001) that are shown in Table 1. Every cock received $125 \mathrm{~g}$ of diet/day at 38 weeks of age, up to140 g/d at the end of the experiment. Birds were healthy, examined against diseases and immunizations.

The statistical analysis was conducted using SAS $^{\circledR}$ (2003) software program, using factorial experimental designs analyses of variance of GLM procedures considering the replicate as the experimental unit. Mean differences were tested at $\mathrm{P} \leq 0.05$ by Student Newman Keuls Test (SAS, 2003) using $\mathrm{P} \leq 0.05$. Before analysis, all percentages were arc sin to normalize data distribution. Data were reported based on the main effects 
W. Ezzat; A. M. Rizk and A.A. Habeib

and their interactions. Hatchability rates were analyzed by the Chi-square test.

\section{RESULTS AND DISCUSSION}

Data presented in Table 1 shows that a significant $(\mathrm{P}<0.01) \quad$ increased sperm motility $(\%)$, and a significant $(\mathrm{P}<0.01)$ decreased dead spermatozoa (\%), abnormal spermatozoa (\%) and acrosomal damage (\%) of cocks consequently, better hatchability rate of hens diluted semen added with nigella sativa oil (NSO) followed by olive oil (OO) compared to the control during different storage time $\left(0,24,48\right.$ and 72 hours at of $\left.5{ }^{\circ} \mathrm{C}\right)$. Percentages of sperm motility, dead spermatozoa, abnormal spermatozoa, and acrosomal damage of cocks and hatchability rate of hens were significantly $(\mathrm{P}<0.01) \quad$ influenced by interaction between treatments and storage time (Figures 1-5). The positive effect of NSO and OO into semen diluent may be attributed to NSO is rich in fatty acid, (oleic, linoleic and linolenic acid) and carotene which is converted into vitamin A (Al-Jassir, 1992) and active ingredients, like thymoquinine, possess reproducible anti-oxidant effects through enhancing the oxidant scavenger system, a consequently lead to antitoxic effects induced by several insults (Salem, 2005). In addition, some unsaturated fatty acids like linoleic acid (about 60\%) and oleic acid (about 20\%) present in NSO may also improve of sperm parameters such as sperm count and sperm motility (Kolahdooz et al., 2014). Nigella sativa has been found to be able to improve of sperm quality in rabbit (Riad et al., 2004). Masella et al. (2004) found that olive oil containing antioxidants had the following effects: 1-completely prevented the oxidation of LDL; 2- counteracted the time - dependent variations in intracellular redox balance، inhibiting the production of $\mathrm{O}_{2}$ and $\mathrm{H}_{2} \mathrm{O}_{2}$ and the decrease in glutathione content; 3restored glutathione reductase and peroxidase activities; and 4- restored the mRNA expression of $\gamma$ - glutamylcisteine synthetase, glutathione reductase, and glutathione peroxidase to control values. Olive oil contains a large amount of natural antioxidants which provide oxidative stability during storage (Boskou et al., 2005). Enhancing the antioxidant capacity of the diluted semen stored at $5^{\circ}$ $\mathrm{C}$ as a result of the addition of $\mathrm{OO}$ or NSO improves the sperm preservation capacity of the cocks by two ways defense towards peroxidative harm is crucial to hold the structural integrity of the spermatozoa and minimization of lipid peroxidation will save you any discount inside the concentrations of the functionally important $\quad$ C $\quad 20 \quad-\quad 22$ polyunsaturated fatty acids of the sperm phospholipids (Al-Daraji, 2012 and Bruits and Bucar, 2000). It is speculated that the development in spermatozoa viability and integrity are a result of antioxidants suppressing or limiting the harmful effects of lipid peroxidation in vitro. Possibly the development to these sperm parameters are at the extent of the membrane, as lipid - and water - and lipid - soluble antioxidants maintained viability, membrane integrity, and motility of turkey sperm after $48 \mathrm{~h}$ in vitro storage, however the water soluble antioxidant examined did now not (Donoghue and Donoghue, 1997). Because in their lipid solubility, olive oil can permeate plasma membrane of spermatozoa and suppress free radical harm. However, Donoghue and Donoghue (1997) found that the antioxidant activity in seminal plasma and sperms isn't enough to prevent lipid peroxide harm after extension and in vitro 
Olive oil-Nigella sativa oil- in vitro storage-semen quality- hatchability.

storage, and those supplemental antioxidants may want to enhance semen shelf existence.

Sperm motility of cocks and hatchability rate of hens were decreased while, dead spermatozoa (\%), abnormal spermatozoa (\%) and acrosomal damage of cocks were significantly $(\mathrm{P}<0.01)$ increased with the increase in storage time of diluted semen from 0 to 72 at $5^{\circ} \mathrm{C}$ (Table 1). These results are in agreement with those results of El-Saadany (2002) who reported that increasing storage time of diluted semen from local chicken breed for 0, 24, 48 and $72 \mathrm{hr}$ significantly $(\mathrm{P}<0.01)$ decreased the fertility rate (FR) by 5.12, 9.55 and $12.53 \%$, respectively. Siudzinska and Lukaszewick (2008) found that during the time of storage, a decrease in live, morphologically normal spermatozoa and an increase of dead spermatozoa and spermatozoa with bent necks were observed. Also, Hudson et al. (2016) found that the percent of dead spermatozoa and abnormal spermatozoa significantly increased with increasing storage periods. Brown et al. (1972) observed that at $5^{\circ} \mathrm{C}$, motility of sperm lasted for longer time period; due to the fact the vital substances wished for power metabolism are conserved. The maintenance of motility during storage was decreased when no energy substrate was present in the extender.

Percentages of sperm motility, dead spermatozoa, abnormal spermatozoa, acrosomal damage of cocks and hatchability rate of hens were significantly $(\mathrm{P}<0.01)$ influenced by interaction between semen diluted supplemented with or without olive oil or Nigella sativa oil and storage time. Sperm motility (\%), dead spermatozoa (\%), abnormal spermatozoa (\%) and acrosomal damage of cocks and hatchability rate of hens were significantly $(\mathrm{P}<0.01)$ improved with NSO followed by OO compared to control semen for all storage periods. The advancement of storage time was significantly $(\mathrm{P}<0.01)$ lower the percentage of sperm motility and hatchability rate in extender semen either with NSO, OO or the control. While, significantly $(\mathrm{P}<0.01) \quad$ higher the percentages of $(\%)$, dead spermatozoa $(\%)$, abnormal spermatozoa (\%) and acrosomal damage of spermatozoa either in the extender semen added with NSO, OO or the control. These results are in agreement with that of Al-Daraji, (2012) who showed that supplementation the diluent of roosters' semen with olive oil can improve semen quality when semen samples in vitro stored at $5{ }^{\circ} \mathrm{C}$ for up to 72 hr. Similarly, Eid et al. (2006) reported that chicken semen during storage reduced sperm numbers reduced motility, increased percentage of dead spermatozoa and raised the level of lipid peroxidation; these changes would lead to lower fertility.

\section{IN CONCLUSION}

addition of nigella sativa oil or olive oil to diluted semen cocks showed increased sperm motility (\%) and decreased dead spermatozoa, abnormal spermatozoa, acrosomal damage of spermatozoa, consequently higher hatchability rate than the control cocks spermatozoa (freenigella sativa or olive oil medium). There, it could be recommended to addition of nigella sativa or olive oil at a level of 1 $\mathrm{ml} / 100 \mathrm{ml}$ extender to extender cock, during at $5{ }^{\circ} \mathrm{C}$ to enhance of hatchability of hens. 
W. Ezzat; A. M. Rizk and A.A. Habeib

Table (1): Ingredients composition and calculated analysis of the basal experimental diet.

\begin{tabular}{|l|c|c|}
\cline { 2 - 3 } & \multicolumn{2}{|c|}{ Diet } \\
\cline { 2 - 3 } Composition (per 100 Kg) & Cocks & Hens \\
\hline Yellow corn & 67.10 & 65.36 \\
Soybean meal (44\% CP) & 18.15 & 18.75 \\
Corn gluten meal (60\% CP) & 1.25 & 2.85 \\
Wheat bran & 9.71 & 3.05 \\
Dicalcium phosphate & 1.75 & 1.50 \\
Limestone & 1.25 & 7.60 \\
Nacl & 0.40 & 0.40 \\
Vit. \& Min. Premix** & 0.30 & 0.30 \\
DL-Methionine & 0.09 & 0.19 \\
Total & 100 & 100 \\
\hline Calculated analysis: ${ }^{* *}$ & & \\
\hline Crude protein (CP); \% & 16.02 & 16.11 \\
ME; kcal/kg & 2828 & 2759 \\
Ether extract & 2.85 & 2.84 \\
Crude fiber & 3.83 & 3.12 \\
Calcium & 0.94 & 3.29 \\
Av. Phosphorus & 0.45 & 0.39 \\
Lysine & 0.73 & 0.72 \\
Methionine & 0.36 & 0.47 \\
Methionine + cystine & 0.66 & 0.77 \\
\hline
\end{tabular}

* Vitamins and mineral premix provides per 3kg: Vit. A 12000 IU; Vit. D $_{3} 2000$ IU; Vit. E. 10mg; Vit. $K_{3} 2 \mathrm{mg}$; Vit.B 1 1mg; Vit. $\mathrm{B}_{2} 4 \mathrm{mg}$; Vit. $\mathrm{B}_{6} 1.5 \mathrm{mg}$; Pantothenic acid 10mg; Vit. $\mathrm{B}_{12}$ $0.01 \mathrm{mg}$; Folic acid 1mg; Niacin, 20mg; Biotin, 0.05mg; Choline chloride (50\% choline) 500 mg; Zn, 55mg; Fe, 30mg; I 1mg; Se, 0.1mg; Mn, 55mg; Ethoxyquin $3000 \mathrm{mg}$.

**Calculated analysis was, according to Feed Composition Tables for Animal and Poultry Feedstuffs used in Egypt (2001). 
Table (2): Semen characteristics and hatchability $\%(\bar{X} \pm S E)$ of Mandarah cocks and hens as affected by olive oil and Nigella sativa oil and their interactions at 38-54 weeks of age.

\begin{tabular}{|c|c|c|c|c|c|}
\hline Items & $\begin{array}{c}\text { Sperm motility } \\
(\%)\end{array}$ & $\begin{array}{c}\text { Dead spermatozoa } \\
(\%)\end{array}$ & $\begin{array}{c}\text { Abnormal } \\
\text { spermatozoa }(\%)\end{array}$ & $\begin{array}{c}\text { Acrosomal damage } \\
(\%)\end{array}$ & $\begin{array}{c}\text { Hatchability/total } \\
\text { eggs }(\%)\end{array}$ \\
\hline Treatments & $* *$ & $* *$ & $* *$ & $* *$ & $* *$ \\
\hline Semen diluted (LD) (Control) & $53.75 \pm 6.83^{b}$ & $35.94 \pm 5.29^{\mathrm{a}}$ & $25.94 \pm 3.70^{\mathrm{a}}$ & $15.57 \pm 2.40^{\mathrm{a}}$ & $46.42 \pm 7.21^{\mathrm{b}}$ \\
\hline Olive oil (OO) & $63.44 \pm 5.86^{\mathrm{b}}$ & $28.75 \pm 4.65^{\mathrm{b}}$ & $19.57 \pm 3.08^{b}$ & $10.38 \pm 1.53^{\mathrm{b}}$ & $56.82 \pm 5.55^{\mathrm{a}}$ \\
\hline Nigella sativa oil (NSO) & $70.94 \pm 5.65^{\mathrm{a}}$ & $26.19 \pm 4.60^{\mathrm{b}}$ & $17.07 \pm 2.85^{\mathrm{b}}$ & $9.13 \pm 1.48^{b}$ & $61.13 \pm 5.24^{\mathrm{a}}$ \\
\hline Storage time (Hours) & $* *$ & $* *$ & $* *$ & $* *$ & $* *$ \\
\hline $0 \mathrm{hr}$ & $87.92 \pm 1.57^{\mathrm{a}}$ & $10.5 \pm 1.19^{\mathrm{d}}$ & $7.17 \pm 0.96^{\mathrm{d}}$ & $4.42 \pm 0.52^{\mathrm{d}}$ & $80.97 \pm 1.39^{\mathrm{a}}$ \\
\hline $24 \mathrm{hr}$ & $76.25 \pm 1.96^{\mathrm{b}}$ & $17.84 \pm 1.13^{\mathrm{c}}$ & $12.25 \pm 0.89^{c}$ & $7.50 \pm 0.78^{c}$ & $70.02 \pm 2.47^{\mathrm{b}}$ \\
\hline $48 \mathrm{hr}$ & $57.09 \pm 3.72^{\mathrm{c}}$ & $34.75 \pm 1.78^{b}$ & $26.09 \pm 1.64^{\mathrm{b}}$ & $13.75 \pm 1.20^{\mathrm{b}}$ & $45.25 \pm 2.29^{c}$ \\
\hline $72 \mathrm{hr}$ & $27.92 \pm 2.79^{d}$ & $58.09 \pm 2.65^{\mathrm{a}}$ & $37.92 \pm 2.21^{\mathrm{a}}$ & $21.09 \pm 2.1^{\mathrm{a}}$ & $22.93 \pm 4.13^{\mathrm{d}}$ \\
\hline $\begin{array}{l}\text { Interaction between treatments } \\
\text { and storage time }\end{array}$ & $* *$ & $* *$ & $* *$ & $* *$ & $* *$ \\
\hline
\end{tabular}

Means having different letters in the same column are significantly $(\mathrm{P}<0.05)$ different 
W. Ezzat; A. M. Rizk and A.A. Habeib
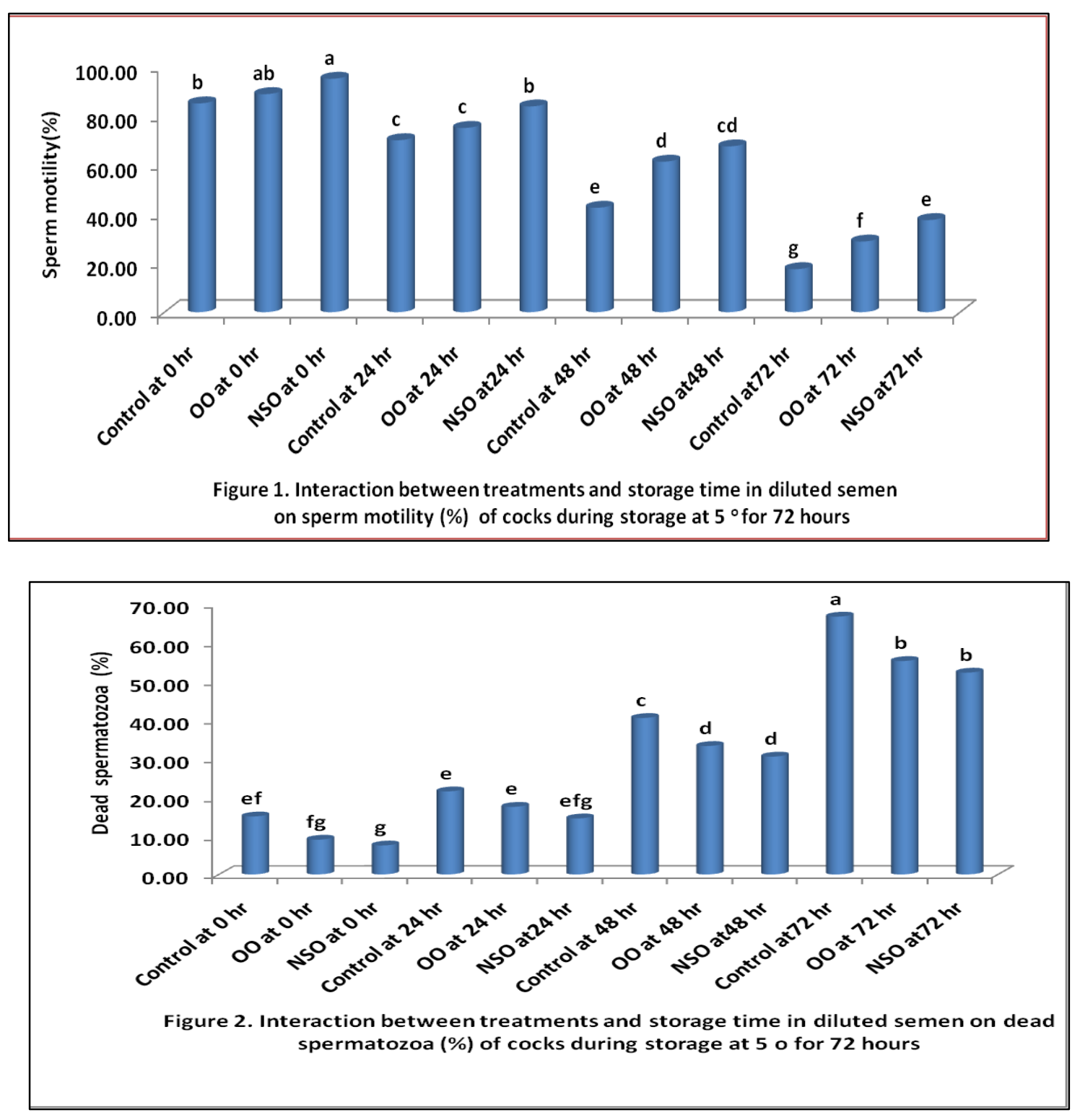
Olive oil-Nigella sativa oil- in vitro storage-semen quality- hatchability.
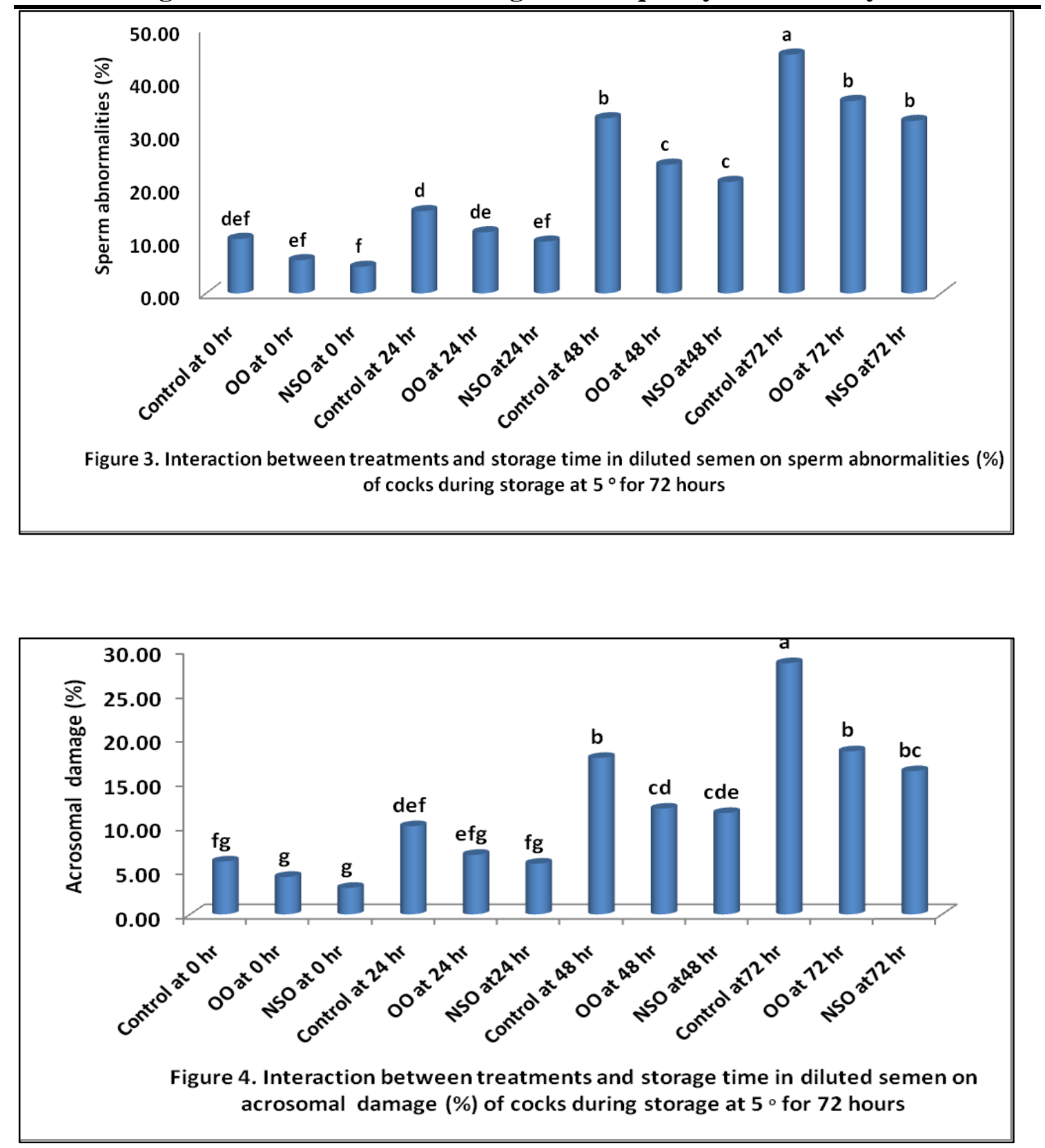


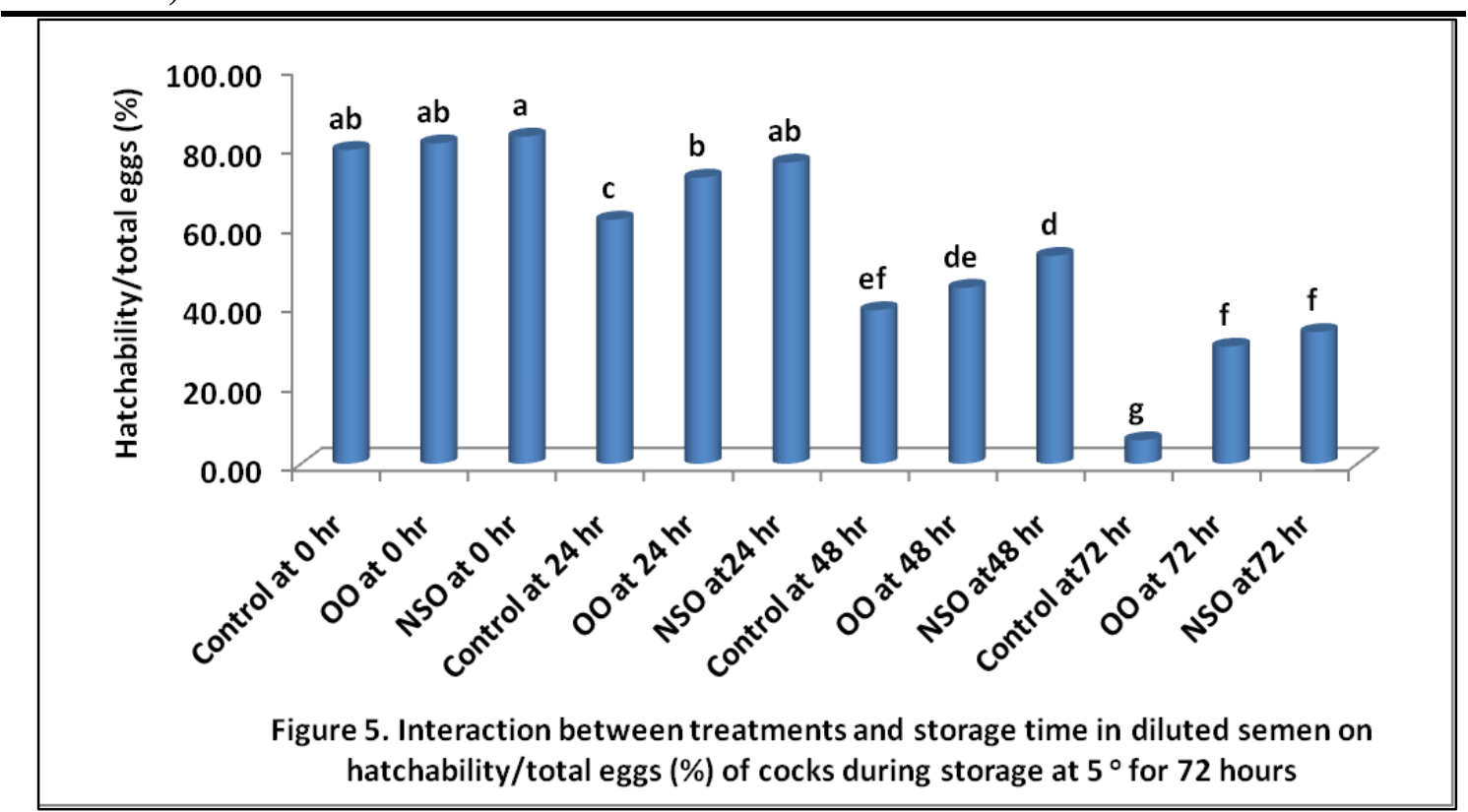

\section{REFERENCES}

Al-Daraji, H.J., 2012. Adding olive oil to rooster semen diluents for improving semen quality and storage ability during liquid storage. South Afr J Anim Sci., 42 (2): 139-145.

Al-Jassir, M. S., 1992. Chemical composition and microflora of black cumin (Nigella sativa L.) seeds growing in Saudi Arabia. Food Chem, 45: 239- 242.

Aurich, J.E.; Schonherr, U.; Hoppe, H. and Aurich, C., 1997. Effects of antioxidants on motility and membrane integrity of chilled stored stallion semen. Theriogenology; 48:185-192.

Ball, B.A.; Medina, V.; Gravance, C.G.; and Baumbe, J., 2001. Effect of antioxidants on preservation of motility, viability and acrosomal integrity of equine spermatozoa during storage at $5^{\circ} \mathrm{C}$. Theriogenology; 56:577-589.

Boskou, D.; Blekas, G. and Tsimidou, M., 2005. Phenolic compounds in olive oil and olives Cur Topics Nut Res.; 3: 125-136.

Brown, K.I.; Graham, E.F. and Crabo, B.G. 1972. Effect of hydrogen ion buffer on storage and freezing of turkey sperm. Poult. Sci., 51: 840-849.

Burits, M. and Bucar, F., 2000. Antioxidant activity of Nigella sativa essential oil. Phytother Res. 14 (5) : 323-328.

Cecil, H.C. and Bakst, M.R., 1993. In vitro lipid peroxidation of turkey spermatozoa. Poult. Sci., $\underline{72}$ : 1370-1378.

Cheikh-Rouhou, S.; Besbes, S.; Hentati, B.; Blecker, C.; Deroanne, C. and Attia, H., 2007. Nigella sativa L.: Chemical composition and physicochemical characteristics of lipid fraction. Food Chem., 101: 673681.

D’Angelo, S.; Manna, C.; Migliardi, V.; Mazzoni, O.; Morrica, P.; Capasso, G.; Pontoni, G.; Galleti, P. and Zappia, V., (2001). Pharmacokinetics, metabolism of 
Olive oil-Nigella sativa oil- in vitro storage-semen quality- hatchability.

hydroxytyrosol, a natural antioxidant from olive oil. DMD; 29(11): 1492 1498.

Donoghue, A. M. and Donoghue, D. J. 1997. Effects of water - and lipid soluble antioxidants on turkey sperm viability, membrane integrity, and motility during liquid storage. Poultry Sci., 76: 1440 - 1445 .

Eid, Y.; Ebeid, T. and Younis, H., 2006. Vitamin E supplementation reduces dexamethasone-induced oxidative stress in chicken semen. British Poultry Sci., 47, (ㅈ): 350-356.

El-Saadany, Amina, Sh., 2002 Use of antioxidants in storing local cockerels semen. M.Sc. Thesis, Alex. Univ., Egypt.

Feed Composition Tables For Animal and Poultry Feedstuffs Used In Egypt 2001. Technical bulletin No.1, central lab for Feed and food; Ministry of Agriculture, Egypt.

Giovannini, C., 2004. Extra virgin olive oil biophenols inhibit cell - mediated oxidation of LDL by increasing the mRNA transcription og glutathione related enzymes. J Nutr., 134: 785 791.

Hudson, G.H. ; Omprakash, A.V. and Premavalli, K. 2016. Effect of semen diluents, dilution rates and storage periods on live and abnormal spermatozoa of pearl guinea fowls. Asian Journal of Animal and Veterinary Advances; 11: 411-416.

Kolahdooz, M.; Nasri, S.; Modarres, S. Z.; Kianbakht, S. and Huseini, H. F., 2014. Effects of Nigella sativa seed oil on abnormal semen quality in infertile men: A randomized, double-blind, placebo-controlled clinical trial. Phytomedicine,21,901-905.
Lake, P. E., 1960. Studies on the dilution and storage of fowl semen. J. Reprod. Fert. 1: 30 - 35. Article.

Masella, R.; Vari, R.; D'Archivio, M.; Di Benedetto, R.; Matarrese, P.; Malorni, W.; $\quad$ Scazzocchio, B. and Giovannini, C., 2004. Extra virgin olive oil biophenols inhibit cell - mediated oxidation of LDL by increasing the mRNA transcription og glutathione - related enzymes. J. Nutr.,134:785 - 791.

Ommati, M. M.; Zamiri, M. J.; Akhlaghi, A.; Atashi, H.; Jafarzadeh, M. R.; Rezvani, M. R. and Saemi, F., 2013. Seminal characteristics, sperm fatty acids, and blood biochemical attributes in breeder roosters orally administered with sage (Salvia officinalis) extract. Anim. Prod. Sci., 53:548-554.

Riad, R. M.; Ghoniem, A. M. and Seleem, T. S. T. 2004. Effect of Nigella sativa (Aquas extract) on the viability of rabbit spermatozoa, fertility traits and bacterial

contamination. Assiut. Vet. Med. J., 130: 899-911.

Salem, M.L., 2005. Immunomodulatory and therapeutic properties of the Nigella sativa L. seed. Review. Int. Immunopharmacol., 5: 1749-1770.

Siegfried, N.L. and Hughes, G., 2012. Herbal medicine, randomised controlled trials and global core competencies. S Afr Med J; 102(12): 912-913.

Siudzinska, A. and Lukaszewick, E. 2008. Effect of semen extenders and storage time on sperm morphology of four roosters breeds. Appl. Poult. Res. 17: 101-108.

Statistical Analyses Software, SAS, 2003. The SAS System for Windows, Release 9.1.3 Service pack 2, TS- 


\section{W. Ezzat; A. M. Rizk and A.A. Habeib}

level 01M3.SAS Inst. Inc., Cary, NC, USA.

Surai, P.F. and N.H.C. Sparks, 2001. Comparative evaluation of the effect of two maternal diets on fatty acids, vitamin $\mathrm{E}$ and carotenoids in the chick embryo. Br. Poult. Sci., 42: 252-259.

Tawfeek F. Kh., Suha. M. Ahmed Soulaf. J. Kakel (2006). Effect of Nigella sativa oil treatment on the sex organs and sperm characters in rats exposed to hydrogen peroxide. Mesopotamia J. Agric., 34. No. 1 .

Watson, P. F., 1975. Use of Giemsa stain to detect changes in acrosomes of freezing ram spermatozoa. Vet. Res., 97:12-15.

Zhang, Y.Y. and Zheng, G.M., 2002. Artificial insemination of Cabot's Tragopan. J. Beijing Normal Univ. Nat. Sci. Ed., 38: 117-122.

\section{الملخص العربي}

تأثير إضافة مضادات الأكسدة الطبيعية علي كفاءة حفظ السائل المنوي لايوك سلالة المندرة

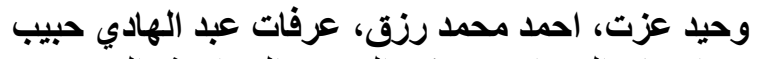

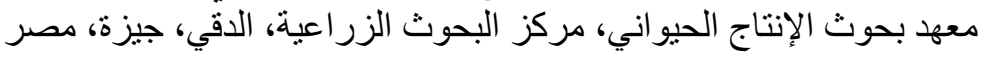

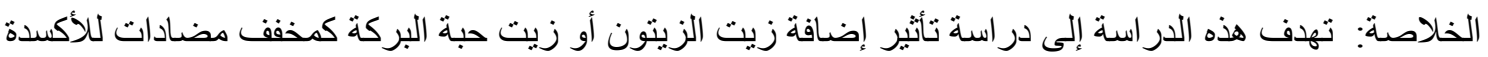

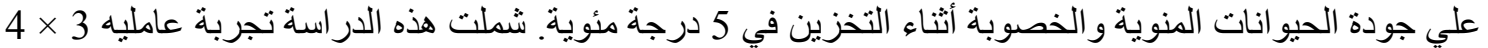

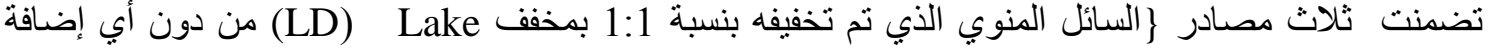

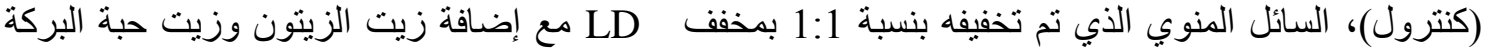

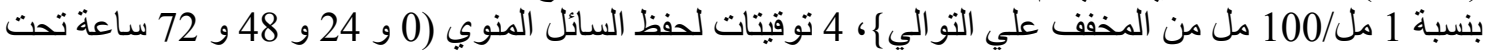
درجة حرارة 5 درجة مئوي). تم استخدام 60 ديك ، 180 دجاجة عمر 38 دأسبو السئا في هذه الدراسة لتوفير بيانات

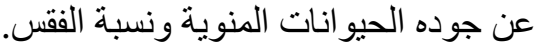

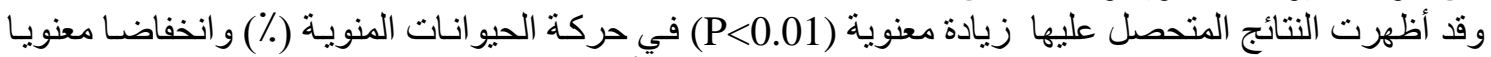

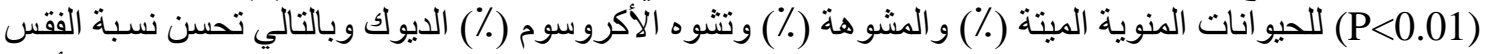

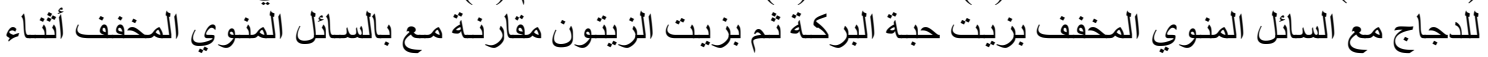

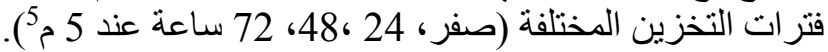

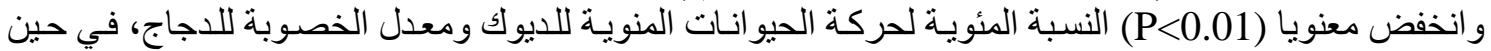

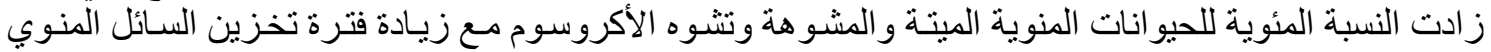
المخفف زالف

ولذلك ، بمكن استخدام زيت حبة البركة أو زيت الزيتون لتحسين صفات جوده السـائل المنوي للديوك عند الحفظ

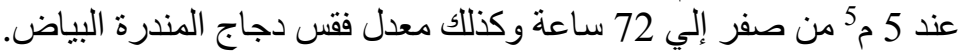

